\title{
Effects of ethanol and protein deficiency on pancreatic digestive and lysosomal enzymes
}

\author{
M V Apte, J S Wilson, M A Korsten, G W McCaughan, P S Haber, R C Pirola
}

\begin{abstract}
The pathogenesis of alcoholic pancreatitis is not fully understood. An increase in pancreatic digestive and lysosomal enzyme synthesis because of ethanol consumption could contribute to the development of pancreatic injury in alcoholics. This study aimed, firstly, to determine the effect of ethanol on the content and messenger RNA levels of pancreatic digestive enzymes and on the messenger RNA level of the lysosomal enzyme cathepsin $B$, and secondly, to examine the influence of concomitant protein deficiency (a known association of alcoholism and pancreatic injury) on these effects. A rat model of chronic ethanol administration was used in which rats were fed in groups of four, and for four weeks, protein sufficient and protein deficient diets with or without ethanol. Ethanol increased the pancreatic content of lipase but did not influence chymotrypsinogen or trypsinogen values. mRNA levels for lipase, trypsinogen, and chymotrypsinogen were raised in rats fed ethanol. Protein deficiency resulted in reduced tissue levels of lipase, chymotrypsinogen, and amylase but did not influence trypsinogen values. mRNA levels for proteases were increased in protein deficient rats, while those for lipase remained unaltered. Both ethanol and protein deficiency increased mRNA levels for cathepsin B. It is concluded that chronic ethanol consumption, in both protein sufficient and protein deficient states, increases the capacity of the pancreatic acinar cell to synthesise digestive and lysosomal enzymes.
\end{abstract}

(Gut 1995; 36: 287-293)

Keywords: ethanol, protein deficiency, pancreatic enzymes.

Alcoholic pancreatitis is a major complication of alcohol abuse. Although the pathogenesis of this condition remains unknown, a number of hypotheses have invoked a role for pancreatic digestive and (possibly) lysosomal enzymes in ethanol induced pancreatic injury. ${ }^{1-3}$ In this regard, Singh et $a l^{4}$ have reported that chronic administration of ethanol as part of a nutritionally adequate liquid diet increases the specific activity of rat pancreatic trypsinogen and chymotrypsinogen. Using a similar diet, Korsten et $a l^{5}$ have recently shown that ethanol increases the content of lipase in acini isolated from rat pancreas. In addition,
Ponnappa et al ${ }^{6}$ have shown increased rates of synthesis of digestive enzymes in pancreatic acini from rats fed ethanol. Our group 7 and others $^{8}$ have also previously reported that chronic ethanol administration to rats increases the pancreatic content of cathepsin B (a lysosomal enzyme known to be capable of activating trypsinogen ${ }^{910}$ ).

The above ethanol related effects on pancreatic digestive and lysosomal enzymes may be mediated by increased messenger RNA levels for these enzymes. This hypothesis, however, has not been investigated previously.

Protein deficiency is a known association of pancreatic injury ${ }^{11}$ and of alcoholism. ${ }^{12}$ Messenger RNA levels for pancreatic digestive enzymes are known to be altered in response to protein deprivation. ${ }^{13}$ The influence of concomitant protein deficiency on content and mRNA levels of pancreatic digestive enzymes has not, however, been studied in rats fed ethanol.

This study aimed to determine:

(1) The effect of chronic ethanol consumption on pancreatic content and messenger RNA levels of four major digestive enzymes lipase, trypsinogen, chymotrypsinogen, and amylase in rats;

(2) The effect of chronic ethanol administration on pancreatic mRNA levels for the lysosomal enzyme cathepsin $\mathrm{B}$; and

(3) The influence of concomitant protein deficiency on the above ethanol related effects.

\section{Methods}

\section{EXPERIMENTAL ANIMALS}

Male weanling Sprague Dawley rats which were littermates were used in all experiments. A quartet-feeding model of experimental ethanol administration was employed: rats, in groups of four, were fed protein sufficient and protein deficient diets with and without ethanol as detailed below.

Thirty two littermate rats weighing $90-100 \mathrm{~g}$ were housed in individual cages and match-fed for four weeks isocaloric amounts of one of four liquid diets: (i) a protein sufficient control diet; (ii) a protein sufficient diet with ethanol; (iii) a protein deficient diet; and (iv) a protein deficient diet with ethanol. Rats fed ethanol received $36 \%$ of energy as ethanol. In the control diet, carbohydrate calories were substituted for ethanol. The protein deficient rat fed ethanol was the rate-limiting animal 
for each quartet. The protein deficient animals received only $2 \%$ of total calories as protein. This relatively severe degree of protein deficiency was instituted to speed up the development of protein deficiency in a relatively short feeding period of four weeks, since preliminary studies ${ }^{5}$ had shown that rats fed larger amounts of protein (4\% of total calories) did not exhibit hypoalbuminaemia even after several months of diet administration. The diet was prepared according to the general formulation of Lieber and DeCarli ${ }^{14}$ and was supplemented with regular vitamins and minerals. As described previously, ${ }^{5}$ care was taken to supplement the diets with adequate choline so that protein deficiency could be studied in the absence of choline deficiency, to which rats are more prone than humans.

Rats were killed by decapitation. In the 24 hour period before killing, the daily quota of liquid diet for each rat was divided into equal amounts and administered at fixed intervals so that the rate at which the diet was ingested was the same for each rat in the quartet. The regulation of energy intake in this way is an important factor for any study examining the effects of dietary constituents on pancreatic digestive enzymes.

\section{PANCREATIC DIGESTIVE ENZYME ASSAYS}

Whole pancreas was removed, debrided of adipose and connective tissue in ice cold saline, and weighed. Approximately $200 \mathrm{mg}$ of pancreas were homogenised in $10 \mathrm{ml}$ of homogenisation buffer $(0.025 \mathrm{M}$ Tris, $2.5 \mathrm{mM}$ $\mathrm{CaCl}_{2}, 0 \cdot 1 \%$ Triton $\mathrm{X}-100, \mathrm{pH} 8.9$ ) using an Ultra Turrax homogeniser (Janke and Kunkel, Germany). An aliquot of this crude homogenate was stored at $-70^{\circ} \mathrm{C}$ for DNA assay, while the remainder was centrifuged at $100000 \mathrm{~g}$ for 30 minutes at $4^{\circ} \mathrm{C}$ in a Beckman ultracentrifuge using a fixed angle, TY-65 rotor to remove particulate matter. The supernatant was divided into aliquots and stored at $-70^{\circ} \mathrm{C}$ for assays of trypsinogen, chymotrypsinogen, lipase, and amylase.

Trypsinogen was assayed as trypsin by the method of Huttunen, ${ }^{15}$ after activation with purified enterokinase. ${ }^{16}$ Chymotrypsinogen was assayed as chymotrypsin, after activation with purified enterokinase, by the method of Hummel et al. ${ }^{17}$ Lipase activity was measured as the rate of change of absorbance at $334 \mathrm{~nm}$ during hydrolysis of triolein to monoglycerides and oleic acid. ${ }^{18}$ Amylase activity was assayed using the method described by Jung. ${ }^{19}$ All enzyme assays were linear with regard to time and protein concentration.

In preliminary experiments, lipase, trypsinogen, and chymotrypsinogen activities were measured in pancreatic homogenates from chow fed rats in the presence of in vitro ethanol (200 $\mathrm{mM}$ final level) and acetaldehyde ( $1 \mathrm{mM}$ final level). This was done to ensure that the assays used to measure the above enzymes were not influenced by the presence of ethanol or its metabolites, or both, in tissue samples from rats fed ethanol.
PROTEIN AND DNA DETERMINATIONS

Tissue protein was measured by the method of Lowry et $a l^{20}$ using bovine serum albumin as the standard. Pancreatic DNA was assayed by a modified fluorimetric microassay as described by Kapuscinski and Skoczylas ${ }^{21}$ using calf thymus DNA as the standard.

\section{ISOLATION OF TOTAL PANCREATIC RNA}

On removal of the whole pancreas, a portion of the gland was snap frozen in liquid nitrogen and stored at $-70^{\circ} \mathrm{C}$ for RNA extraction. Total pancreatic RNA was isolated by a modification of the method described by Chomczynski and Sacchi. ${ }^{22}$ Briefly, pancreatic tissue (maintained in a frozen state using liquid nitrogen) was powdered in a mortar and pestle (precooled with liquid nitrogen) and then added to $10 \mathrm{ml}$ of a buffer containing $4 \mathrm{M}$ guanidinium thiocyanate (RNAase inhibitor), $25 \mathrm{mM}$ sodium citrate $\mathrm{pH} 7 \cdot 0,0 \cdot 5 \%$ sarcosyl, and $0.1 \mathrm{M}$ 2-mercaptoethanol. RNA was then extracted using phenol and chloroformisoamyl alcohol (49:1), ethanol precipitated, resuspended in diethylpyrocarbonate treated autoclaved water, and quantitated spectrophotometrically. The $A_{260} / A_{280}$ of the RNA samples was routinely in the range of $1 \cdot 6-1 \cdot 7$. Agarose gel electrophoresis of extracted RNA confirmed that the RNA samples were not degraded.

\section{ANALYSIS OF RNA}

\section{Northern blotting of $R N A$}

Qualitative analysis of total RNA was performed using the northern blotting technique. RNA was denatured with formaldehyde, subjected to electrophoresis through $1 \%$ agarose containing formaldehyde, and transferred by vacuum blotting to a positively charged nylon membrane (Hybond $\mathrm{N}+$, Amersham, UK). An RNA ladder (Gibco, BRL, Gaithersburg, MD) was used for size determination.

\section{Dot blotting of RNA}

Quantitative comparisons of messenger RNA were made using the dot blotting technique. RNA samples were denatured and dot blotted in duplicate in two different dilutions ( 2 and 4 $\mu \mathrm{g}$ RNA per sample) onto nylon membranes (Zeta Probe, GT blotting membrane, BIORAD, California). Membranes were rinsed in $2 \times$ sodium chloride sodium citrate (SSC), $0 \cdot 1 \%$ sodium dodecyl sulphate (SDS), sealed in Cling Wrap, and stored at $-20^{\circ} \mathrm{C}$ until further use.

Radiolabelling of cDNA probes

cDNA probes for lipase, trypsinogen, chymotrypsinogen, amylase, and cathepsin B were radiolabelled with $\left[{ }^{32} \mathrm{P}\right]$-deoxycytosine triphosphate using a random priming kit (Megaprime DNA labelling systems, Amersham, UK). Unincorporated nucleotides 
were removed using nucleic acid purification columns (NENSORB 20 cartridges, Du Pont, USA). The incorporation of label thus obtained was routinely between $4-6 \times 10^{8}$ $\mathrm{cpm} / \mu \mathrm{g}$ DNA.

An oligonucleotide probe (5' CTC GTC ATA CTC CTG CTT GCT GAT C $3^{\prime}$ ) for rat pancreatic $\beta$-actin was used as an internal control to ensure that equal amounts of RNA were loaded onto the membranes. This probe was radiolabelled using a $5^{\prime}$ end labelling kit (NEN oligonucleotide $5^{\prime}$ end-labelling kit, Du Pont, USA).

\section{Prehybridisation and hybridisation}

When using cDNA probes, filters were prehybridised in $10 \mathrm{ml}$ of a solution containing $5 \times$ SSC, $0.025 \mathrm{M}$ sodium phosphate buffer pH $7 \cdot 0,0.1 \%$ SDS, $0.5 \mathrm{mg} / \mathrm{ml}$ salmon sperm DNA and $5 \times$ Denhardt's solution. Prehybridisation was carried out for one hour at a temperature of $68^{\circ} \mathrm{C}$ for lipase and cathepsin $\mathrm{B}$ and $60^{\circ} \mathrm{C}$ for trypsinogen, chymotrypsinogen and amylase. When using the oligonucleotide probe for $\beta$-actin, the prehybridising mix contained $5 \times$ SSC, $0.02 \mathrm{M}$ sodium phosphate buffer, $\mathrm{pH} 6.6,7 \%$ SDS, $100 \mu \mathrm{g} / \mathrm{ml}$ ssDNA, and $10 \times$ Denhardt's solution and prehybridisation was carried out at $37^{\circ} \mathrm{C}$ for one hour. ${ }^{23}$

After prehybridisation, $1 \times 10^{6} \mathrm{cpm}$ of the relevant radiolabelled probe was added per $\mathrm{ml}$ of prehybridisation mix and filters were hybridised overnight at the temperatures noted above.

Filters hybridised with cDNA probes were then washed firstly in $1 \times$ SSC, $0 \cdot 1 \%$ SDS for 30 minutes at room temperature, followed by four washes ( 30 minutes $\times 2,60$ minutes $\times 1$, and 30 minutes $\times 1$ ) in $0.2 \%$ SSC, $0 \cdot 1 \%$ SDS at $68^{\circ} \mathrm{C}$ for lipase and cathepsin $\mathrm{B}$ and $60^{\circ} \mathrm{C}$ for trypsinogen, chymotrypsinogen, and amylase. Filters hybridised with $\beta$-actin were washed twice at $37^{\circ} \mathrm{C}$ for 30 minutes each in $3 \times$ SSC, $10 \times$ Denhardt's, $5 \%$ SDS, and 0.025 $\mathrm{M}$ sodium phosphate $\mathrm{pH} 7 \cdot 5$.

\section{Autoradiography and densitometry}

Washed filters were blotted dry, wrapped in Cling Wrap, and exposed to autoradiography film (Eastman Kodak Company, NY, USA). Conditions for autoradiography, that is, linearity with RNA level (2-10 $\mu \mathrm{g}$ RNA) and time of exposure were established in preliminary experiments. Bound radioactivity was determined by subjecting the auto- radiographs to video densitometry (Tracktel, Vision Systems, Adelaide, South Australia). Densitometry readings were expressed as volume\% (arbitrary video densitometer units calculated from the density as well as the size of each dot) per $\mu \mathrm{g}$ RNA loaded on the membranes.

\section{STATISTICAL ANALYSIS}

All data are expressed as mean (SEM). Data were analysed by two way analysis of variance (ANOVA). ${ }^{24}$ Fisher's protected least significant difference (PLSD) test was used where necessary for comparison of individual groups provided the F test was significant. ${ }^{24} 25$ These analyses were run on a Macintosh IIcx personal computer using the Statview II statistical program. ${ }^{25}$

\section{MATERIALS}

All chemicals were of analytical reagent grade and were purchased from the Sigma Chemical Company (St Louis, MO). ${ }^{32} \mathrm{P}$-dCTP (specific activity $3000 \mathrm{Ci} / \mathrm{mmol}$ ) was purchased from Amersham, UK. Molecular biology reagents were obtained from Bio-Rad Laboratories, California, USA. cDNA probes for trypsinogen I (804 bp), chymotrypsinogen $\mathrm{B}(400 \mathrm{bp})$, and amylase $(700 \mathrm{bp}$ ) inserted into the plasmid pBR322, were generously donated by $\mathrm{R}$ McDonald, Dallas, USA. The cDNA probe for lipase (707 bp insert in pUC9) was a kind gift from C Wicker, Marseille, France while that for cathepsin B (800 bp insert in prCB5) was kindly provided by D Steiner, Chicago, USA. The oligonucleotide probe for $\beta$-actin was donated by A Bishop, Sydney, Australia.

\section{ETHICS APPROVAL}

This project was approved by the Animal Care and Ethics Committee, University of New South Wales, Sydney, Australia.

\section{Results}

GENERAL PARAMETERS (TABLE I)

Rats fed the protein sufficient diet gained weight over the feeding period. As observed previously, ${ }^{5}$ protein deficient rats fed the protein deficient diet with and without ethanol exhibited a weight loss of $20 \cdot 2(1 \cdot 5) \%$ and $23 \cdot 2$ $(2 \cdot 1) \%$ of starting body weight respectively. The mean caloric intake (kcal/g/day) was

TABLE I Effect of ethanol and protein deficiency on body and pancreatic weights (values, mean (SEM))

\begin{tabular}{|c|c|c|c|c|}
\hline & $\begin{array}{l}\text { Protein sufficient } \\
\text { diet without } \\
\text { ethanol }\end{array}$ & $\begin{array}{l}\text { Protein sufficient } \\
\text { diet with } \\
\text { ethanol }\end{array}$ & $\begin{array}{l}\text { Protein deficient } \\
\text { diet without } \\
\text { ethanol }\end{array}$ & $\begin{array}{l}\text { Protein deficient } \\
\text { diet with } \\
\text { ethanol }\end{array}$ \\
\hline $\begin{array}{l}\text { Caloric intake }(\mathrm{kcal} / \mathrm{g} / \text { day) } \\
\% \text { Change in body weight } \\
\text { Pancreas weight }(\mathrm{g} / 100 \mathrm{~g} \text { body weight }) \dagger \\
\text { DNA (mg/organ) } \ddagger \\
\text { Protein mg/organ§ }\end{array}$ & $\begin{array}{c}0.28(0.008) \\
15 \cdot 8(3.4) \\
0.61(0.02) \\
1.96(0.07) \\
179 \cdot 6(8 \cdot 7)\end{array}$ & $\begin{array}{l}0.28(0.007) \\
7 \cdot 96(5 \cdot 3) \\
0.57(0.03) \\
2 \cdot 19(0.05) \\
156 \cdot 2(4 \cdot 4)\end{array}$ & $\begin{array}{c}0.29(0.007) \\
-20 \cdot 2(1.49) \\
0.52(0 \cdot 03) \\
1 \cdot 86(0.05) \\
90 \cdot 8(3 \cdot 8)\end{array}$ & $\begin{array}{c}0.28(0.007) \\
-23 \cdot 2(2 \cdot 06) \\
0.48(0.03) \\
1.73(0.05) \\
92 \cdot 2(9.3)\end{array}$ \\
\hline
\end{tabular}

Two way ANOVA: * protein deficiency effect $p<0.02$; †protein deficiency effect $p<0.003$; łprotein deficiency effect $p<0.02$; §protein deficiency effect $\mathrm{p}<0 \cdot 002$. 
TABLE II Effect of ethanol and protein deficiency on rat pancreatic digestive enzymes (values, mean (SEM))

\begin{tabular}{|c|c|c|c|c|}
\hline Enzyme & $\begin{array}{l}\text { Protein sufficient } \\
\text { diet without } \\
\text { ethanol }\end{array}$ & $\begin{array}{l}\text { Protein sufficient } \\
\text { diet with } \\
\text { ethanol }\end{array}$ & $\begin{array}{l}\text { Protein deficient } \\
\text { diet without } \\
\text { ethanol }\end{array}$ & $\begin{array}{l}\text { Protein deficient } \\
\text { diet with } \\
\text { ethanol }\end{array}$ \\
\hline \multicolumn{5}{|l|}{ Lipaset: } \\
\hline U/mg protein ${ }^{\star}$ & $39 \cdot 5(3 \cdot 1)$ & $60 \cdot 5(6 \cdot 3)$ & $18 \cdot 9(2 \cdot 6)$ & $30 \cdot 8(4 \cdot 5)$ \\
\hline $\mathrm{U} / \mathrm{g}$ pancreas $/ 100 \mathrm{~g}$ body weight ${ }^{\star \star}$ & $5740.9(486.8)$ & $7984 \cdot 0(865 \cdot 2)$ & $2387 \cdot 8(340 \cdot 8)$ & $4332 \cdot 1(709 \cdot 4)$ \\
\hline \multicolumn{5}{|l|}{ Trypsinogen: } \\
\hline U/mg protein & $95 \cdot 8(11 \cdot 1)$ & $103 \cdot 3(22 \cdot 2)$ & $93 \cdot 1(10 \cdot 5)$ & $91 \cdot 4(15 \cdot 7)$ \\
\hline $\mathrm{U} / \mathrm{mg}$ pancreas $/ 100 \mathrm{~g}$ body weight & $13 \cdot 5(1 \cdot 1)$ & $13.8(3.5)$ & $11.7(1 \cdot 2)$ & $12 \cdot 4(1 \cdot 5)$ \\
\hline \multicolumn{5}{|l|}{ Chymotrypsinogen $\ddagger$ : } \\
\hline $\mathrm{U} / \mathrm{mg}$ protein $\star$ & $6 \cdot 24(0 \cdot 38)$ & $6.42(0.77)$ & $2.40(0.38)$ & $3.36(0.48)$ \\
\hline $\mathrm{U} / \mathrm{mg}$ pancreas $/ 100 \mathrm{~g}$ body weight ${ }^{\star \star}$ & $0.89(0.09)$ & $0.95(0.15)$ & $0.33(0.04)$ & $0.45(0.06)$ \\
\hline \multicolumn{5}{|l|}{ Amylasef: } \\
\hline U/mg protein $\star$ & $66 \cdot 7(6 \cdot 9)$ & $3.78(0.51)$ & $9 \cdot 1(1 \cdot 2)$ & $6 \cdot 1(1 \cdot 1)$ \\
\hline $\mathrm{U} / \mathrm{g}$ pancreas $/ 100 \mathrm{~g}$ body weight ${ }^{\star \star}$ & $9790.0(1143.9)$ & $517 \cdot 5(95 \cdot 4)$ & $1113.0(92 \cdot 3)$ & $867 \cdot 3(177 \cdot 7)$ \\
\hline
\end{tabular}

Two way ANOVA: $t^{\star}$ ethanol effect $\mathrm{p}<0.002$; protein deficiency effect $\mathrm{p}<0.0002$, ${ }^{\star}$ ethanol effect $\mathrm{p}<0.0005$; protein deficiency effect $p<0.0002 ; \ddagger^{\star}$ protein deficiency effect $p<0.0002$, $\star \star$ protein deficiency effect $p<0.0002 ; \delta^{\star}$ ethanol effect $p<0.0002 ;$ protein deficiency effect $p<0.0002,{ }^{\star}$ ethanol effect $p<0.002$; protein deficiency effect $p<0.0002$.

similar in all four groups. Protein deficient rats had significantly lower pancreatic weights, pancreatic protein content, and DNA levels. Ethanol itself had no effect on these parameters.

\section{PANCREATIC DIGESTIVE ENZYME CONTENT (TABLE II)}

\section{Ethanol effects}

Ethanol feeding increased the pancreatic content of lipase in this model but did not significantly alter trypsinogen or chymotrypsinogen activities. Amylase activities were dramatically reduced in ethanol fed rats compared with controls.

\section{Protein deficiency effects}

Protein deficient animals showed a significant decrease in the pancreatic content of lipase, chymotrypsinogen, and amylase. The pancreatic trypsinogen content, however, was maintained at control (protein sufficient) levels.

\section{Influence of concomitant protein deficiency on ethanol effects}

The effects of ethanol on pancreatic lipase and amylase content (described above) persisted in the presence of concomitant protein deficiency. Thus, protein deficient rats fed ethanol had significantly higher pancreatic

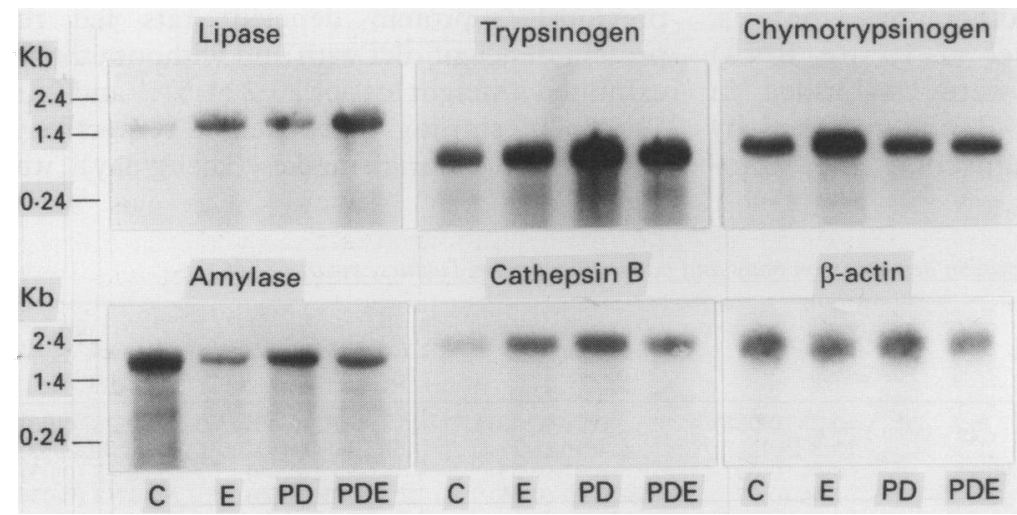

Figure 1: Northern blots showing the effects of ethanol and protein deficiency on pancreatic digestive and lysosomal enzymes in rats fed a protein sufficient diet with (E) and without (C) ethanol and a protein deficient diet with (PDE) and without (PD) alcohol. lipase and lower amylase activities when compared with protein deficient rats not fed ethanol. Pancreatic trypsinogen and chymotrypsinogen activities were similar protein deficient rats fed or not fed ethanol.

\section{MESSENGER RNA CONCENTRATIONS}

Northern blots (Fig 1) for each enzyme using RNA from a quartet of animals showed that the mRNA detected was of the expected size without any degradation. The density of $\beta$-actin (internal control) bands was similar in all four groups and confirmed that there was equal loading of RNA on the filters.

Dot blots of RNA from a representative quartet of rats are shown in Figure 2. Results of densitometry of dot blots of RNA from all animals are shown in Table III. mRNA concentrations for $\beta$-actin (internal control) were similar in all four groups and confirmed that there was equal loading of RNA on the filters.

\section{Ethanol effects}

Rats fed ethanol had significantly higher mRNA levels for lipase, trypsinogen, and chymotrypsinogen. mRNA concentrations for the lysosomal enzyme cathepsin B were increased almost twofold, while those for amylase were reduced to one eighth of control values.

\section{Protein deficiency effects}

Protein deficient animals showed a fourfold increase in mRNA levels for trypsinogen compared with protein sufficient controls. mRNA levels for chymotrypsinogen were also increased while those for lipase remained unchanged. Amylase mRNA values were significantly lower in protein deficient rats. mRNA levels for the lysosomal enzyme, cathepsin $\mathrm{B}$, were significantly higher in protein deficient animals.

\section{Influence of concomitant protein deficiency on ethanol effects}

The effect of ethanol on mRNA levels for lipase, chymotrypsinogen, amylase, and the lysosomal enzyme cathepsin B persisted in the presence of concomitant protein deficiency. 
TABLE III Effect of ethanol and protein deficiency on rat messenger RNA concentrations of pancreatic digestive enzymes and the lysosomal enzyme cathepsin $B$ (values, mean $(S E M))$

\begin{tabular}{lllll}
\hline & $\begin{array}{l}\text { Protein sufficient } \\
\text { diet without } \\
\text { ethanol }\end{array}$ & $\begin{array}{l}\text { Protein sufficient } \\
\text { diet with } \\
\text { ethanol }\end{array}$ & $\begin{array}{l}\text { Protein deficient } \\
\text { diet without } \\
\text { ethanol }\end{array}$ & $\begin{array}{l}\text { Protein deficient } \\
\text { diet with } \\
\text { ethanol }\end{array}$ \\
\hline Lipase & $1 \cdot 11(0 \cdot 19)$ & $4 \cdot 20(0 \cdot 22)$ & $1 \cdot 02(0 \cdot 21)$ & $3 \cdot 09(0 \cdot 35)$ \\
Trypsinogen† & $0 \cdot 98(0 \cdot 12)$ & $1 \cdot 77(0 \cdot 29)$ & $4 \cdot 38(0 \cdot 69)$ & $3 \cdot 88(0 \cdot 48)$ \\
Chymotrypsinogen $\ddagger$ & $1 \cdot 14(0 \cdot 21)$ & $3 \cdot 89(0 \cdot 36)$ & $1 \cdot 84(0 \cdot 24)$ & $2 \cdot 38(0 \cdot 26)$ \\
Amylase & $5 \cdot 17(0 \cdot 89)$ & $0 \cdot 76(0 \cdot 12)$ & $2 \cdot 66(0 \cdot 26)$ & $1 \cdot 79(0 \cdot 14)$ \\
Cathepsin B\| & $1 \cdot 52(0 \cdot 16)$ & $2 \cdot 95(0 \cdot 39)$ & $2 \cdot 42(0 \cdot 24)$ & $2 \cdot 30(0 \cdot 26)$ \\
$\beta$-actin & $2 \cdot 70(0 \cdot 44)$ & $2 \cdot 64(0 \cdot 35)$ & $2 \cdot 70(0 \cdot 14)$ & $2 \cdot 61(0 \cdot 34)$
\end{tabular}

Values are expressed as volume\% (video densitometer units) per $\mu \mathrm{g}$ RNA.

Two way ANOVA: ^ethanol effect $\mathrm{p}<0.0005$; fethanol effect $\mathrm{C} v \mathrm{E} \mathrm{p}<0.05$ (Fisher's PLSD) łethanol effect $\mathrm{p}<0.0005$; protein deficiency effect $\mathrm{C} v$ PD $\mathrm{p}<0.05$ (Fisher's PLSD); Sethano effect $\mathrm{p}<0.0002$; protein deficiency effect $\mathrm{C} v$ PD $\mathrm{p}<0.05$ (Fisher's PLSD); \|ethanol effect $\mathrm{p}<0.025 ;$ protein deficiency effect $\mathrm{C} v$ PD $\mathrm{p}<0.05$ (Fisher's PLSD).

CORRELATION BETWEEN MRNA CHANGES AND FINAL CONTENT OF DIGESTIVE ENZYMES

It was observed that the percentage increase in mRNA levels for lipase, chymotrypsinogen, and trypsinogen in ethanol fed rats was greater than any change in the pancreatic content of the corresponding enzyme. For example, mRNA for lipase increased by $281 \%$ in rats fed the protein sufficient ethanol diet while the enzyme content increased by only $40 \%$. Similar differences were noted between mRNA increases and content of trypsinogen and chymotrypsinogen.

In protein deficient rats, the observed increase in mRNA levels for trypsinogen and chymotrypsinogen did not correlate with the pancreatic content of these enzymes. Messenger RNA levels for trypsinogen were increased by $346 \%$ but the glandular content of the enzyme remained unchanged. With regard to chymotrypsinogen, mRNA levels were increased by $61 \%$ but the pancreatic content of the enzyme was $62 \%$ lower than that in protein sufficient controls.

\section{Discussion}

This study has shown that chronic consumption of ethanol increases pancreatic messenger RNA levels for lipase, trypsinogen, and chymotrypsinogen, as well as for the lysosomal enzyme cathepsin B. These effects of ethanol persisted in the presence of concomitant protein deficiency and suggest that the capacity of the pancreatic acinar cell to synthesis digestive

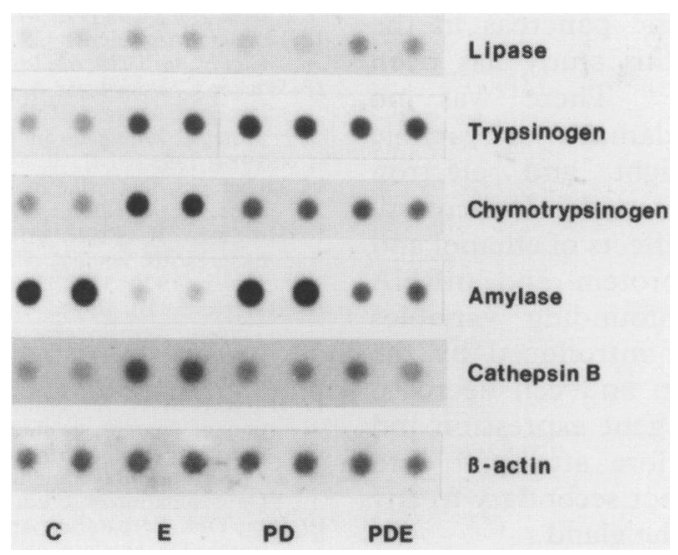

Figure 2: Dot blots of RNA showing the effects of ethanol and protein on pancreatic digestive and lysosomal enzymes. For abbreviations see Figure 1. and lysosomal enzymes is significantly increased after chronic ethanol consumption in both protein sufficient and protein deficient states.

With respect to the glandular enzyme content (Table II), ethanol administration resulted in higher lipase levels in rat pancreas, while the trypsinogen and chymotrypsinogen contents remained unchanged. In contrast, the pancreatic amylase content was considerably lower in rats fed ethanol. The observed reduction in the content of pancreatic amylase in ethanol fed rats (Table II) has been reported previously. ${ }^{26}$ Part of this effect is probably related to the lower carbohydrate content of the diet containing ethanol. Messenger RNA levels for amylase were also reduced after chronic ethanol consumption and may represent an adaptive response of the cell to the reduced carbohydrate content of the diet containing ethanol because mRNA levels for amylase are known to be regulated by the dietary carbohydrate content. ${ }^{27}$ In addition, ethanol, per se, may directly reduce the pancreatic amylase content, as Ponnappa et $a l^{26}$ have shown that a low carbohydrate diet containing ethanol results in lower amylase levels than a low carbohydrate diet alone.

Protein deficiency resulted in lower chymotrypsinogen content of the pancreas, while the trypsinogen content of the gland remained unaltered. This finding is similar to the report by Schick et al $^{28}$ of decreased chymotrypsinogen and unchanged trypsinogen contents in the pancreas of rats fed a low protein diet. The pancreatic lipase content was also low in protein deficient animals in our study. This was probably the result of decreased synthesis of lipase, as has been shown previously by Schick et $a l^{28}$ in protein deficient rats. Under conditions of protein deprivation, the pancreatic acinar cell seems to redirect selectively the synthesis of proteins towards the production of certain anionic proteins, such as trypsinogen, at the expense of cationic proteins, such as lipase. It has been suggested that such a selective response may represent an adaptive response of the acinar cell, important for survival during protein deprivation. ${ }^{28}$ Consistent with the findings of Wicker et al, ${ }^{13}$ mRNA levels for trypsinogen and chymotrypsinogen were raised in protein deficient rats (Table III). It was interesting to note that the increase in mRNA levels for trypsinogen was considerably greater than that for chymotrypsinogen. This observation may explain how the trypsinogen content was maintained in protein deficiency, possibly at the expense of chymotrypsinogen, because of the limited availability of amino acids.

The pancreatic amylase content was lower in protein deficient animals, despite the high carbohydrate content of the protein deficient diet. This result is similar to that described by Schick et $a{ }^{28}$ who found that in rats fed protein deficient diets, amylase levels were lower despite the increased carbohydrate content of the diet. Messenger RNA levels for amylase were also reduced in protein deficient rats, even though the carbohydrate content of 
protein deficient diets was higher than that of protein sufficient diets. These findings are in keeping with the report of Wicker et al ${ }^{13}$ that severe protein deficiency reduces functional mRNA levels for amylase, even in the presence of high dietary carbohydrate, as a result of nonadaptive changes in the pancreatic acinar cell.

In this study, the increased capacity for synthesis of digestive enzymes as a result of increased mRNA levels did not seem to be fully expressed in the cell. In rats fed ethanol as part of a nutritionally adequate diet, the observed difference between changes in mRNA levels and digestive enzyme content could have a number of explanations:

(1) The presence of ethanol or its metabolites, or both, in the homogenates of rats fed ethanol might have interfered with the assays for the above enzymes. However, in vitro ethanol $(200 \mathrm{mM})$ or acetaldehyde $(1 \mathrm{mM})$ did not influence lipase, trypsinogen, or chymotrypsinogen levels (data not shown).

(2) Ethanol may have had an inhibitory effect on ribosomal translation of messenger RNAs in the acinar cell.

(3) Chronic ethanol administration may have altered other variables (apart from the mRNA level for an enzyme) which determine the final cellular content of an enzyme, such as the rates of enzyme synthesis, secretion, and degradation. Indeed, Ponnappa et $a l^{29}$ have reported that the continued presence of ethanol in vivo may exert an inhibitory effect on the synthesis of digestive enzymes, since overnight withdrawal of ethanol was necessary to demonstrate increased in vivo rates of digestive enzyme synthesis in ethanol fed rats.

In protein deficient rats, the observed difference between changes in mRNA levels and protein content is probably due to the limited availability of dietary amino acids preventing the acinar cell from responding fully to the increased levels of digestive enzyme mRNA.

In contrast to the differences in mRNA levels and glandular content observed with digestive enzymes, a close correlation was observed between the ethanol induced increase in mRNA levels for the lysosomal enzyme cathepsin $B$ and the previously reported increase in pancreatic content of the enzyme $\left(94 \cdot 1 \% v 102 \cdot 3 \%\right.$ respectively). ${ }^{7}$

The morphology of the pancreas in the animal model used in this study has been described previously. ${ }^{30} 31$ There was no evidence of organelle damage or vacuole formation (at both light and electron microscopic levels) in this model. It therefore permitted a study of the effects of ethanol and protein deficiency on protein and mRNA levels without the confounding variables which would have been introduced by the presence of inflammation and cell necrosis. The observed changes in gene expression and enzyme levels are therefore attributable to ethanol as such and are not secondary to any inflammatory change in the gland.

This study has shown that chronic ethanol consumption, even in the presence of protein deficiency, significantly increases the capacity (at the mRNA level) of the acinar cell for synthesis of digestive enzymes as well as the lysosomal enzyme cathepsin B. The results of this study may be of relevance to those hypotheses which postulate a role for pancreatic enzymes in ethanol related pancreatic injury including:

(1) Intraductular protein precipitation ${ }^{1}$ causing ductular obstruction and acinar cell atrophy and fibrosis; and

(2) Premature intraglandular activation of digestive enzymes occurring as a direct toxic effect of ethanol on acinar cells, ${ }^{2}$ or secondary to ethanol-induced sphincteric dysfunction. ${ }^{3}$

It is possible that the observed ethanol induced changes in pancreatic enzymes, while insufficient to cause pancreatitis themselves, may predispose the pancreas to injury in the presence of an appropriate, as yet undefined, trigger factor. In this regard, it is of interest to note that chronic ethanol administration has been recently reported to increase the severity of careulein-induced pancreatitis in rats. ${ }^{32}$

Supported by the National Health and Medical Research Council of Australia.

The authors are grateful to the Molecular Genetics Unit, Prince of Wales Hospital, Sydney, for the use of the video densitometer.

1 Sarles H. Chronic calcifying pancreatitis - chronic alcoholic pancreatitis. Gastroenterology 1974; 66: 604-16.

2 Wilson JS, Korsten MA, Pirola RC. Alcohol-induced pancreatic injury (Part I). Unexplained features and ductular theories of pathogenesis. Int $\mathcal{F}$ Pancreatol 1989; 4: 109-25.

3 Wilson JS, Korsten MA, Thomas MC, Pirola RC. The drinker's pancreas: enhanced synthesis of zymogens, secretory block, and lysosomal fragility in the pathogenesis of alcoholic pancreatitis. Int $\mathcal{F}$ Pancreatol 1990; 5: 343-50.

4 Singh $M$, Simsek $H$. Ethanol and the pancreas: current status. Gastroenterology 1990; 98: 1051-62.

5 Korsten MA, Wilson JS, Lieber CS. Interactive effects of dietary protein and ethanol on rat pancreas: protein synthesis and enzyme secretion. Gastroenterology 1990; 99. 229-36.

6 Ponnappa BC, Hoek JB, Jubinski L, Rubin E. Effect of chronic ethanol ingestion on pancreatic protein synthesis. Biochim Biophys Acta 1988; 966: 390-402.

7 Wilson JS, Korsten MA, Apte MV, Thomas MC, Haber PS, Pirola RC. Both ethanol consumption and protein deficiency increase the fragility of pancreatic lysosomes. f Lab Clin Med 1990; 115: 749-55.

8 Singh M, LaSure MM, Bockman DE. Pancreatic acinar cell function and morphology in rats chronically fed an function and morphology in rats chronically

9 Greenbaun LM, Hirshkowitz A. Endogenous cathepsin activates trypsinogen in extracts of dog pancreas. Proc Soc activates trypsinogen in extracts

10 Saluja A, Dawra R, Saluja M, Maitre N, Runzi M, Nishino $\mathrm{H}$, Steer ML. The pH-dependence of trypsinogen activation by cathepsin B. Gastroenterology 1993; 104(4, part 2): A333.

11 Pitchumoni CS. Pancreas in primary malnutrition disorders. Am F Clin Nutr 1973; 26: 374-9.

12 Korsten MA, Lieber CS. Nutrition in the alcoholic. Med Clin N Am 1979; 63: 963-72.

13 Wicker C, Puigserver A, Scheele G. Dietary regulation of levels of active mRNA coding for amylase and serine protease zymogens in the rat pancreas. Eur $¥$ Biochem protease zymogens

14 Lieber CS, DeCarli LM. The feeding of alcohol in liquid diets. Alcohol Clin Exp Res 1986; 10: 550-3.

15 Huttunen R. Proteolytic enzymes in experimental rat pancreatitis. Annales Medicinae Experimentalis et Biologae Fenniae 1973; 51: 133-8.

16 Haverback BJ, Dyce B, Bundy H, Edmondson HA Trypsin, trypsinogen and trypsin inhibitor in huma pancreatic juice. Mechanism for pancreatitis associated with hyperparathyroidism. Am f Med 1960; 29: 424-33.

17 Hummel BCW. A modified spectrophotometric determination of chymotrypsin, trypsin and thrombin. Canadian fournal of Biochemistry and Physiology 1959; 37: 1393-9.

18 Ziegenhorn J, Neumann U, Knitsch KW, Zwez W. Determination of serum lipase. Clin Chem 1979; 25: 1067.

19 Jung DH. Preparation and application of procion yellow starch for amylase assay. Clin Chim Acta 1980; 100: 7-11.

20 Lowry OH, Rosebrough NJ, Farr AL, Randall RJ. Protein measurement with the folin phenol reagent. $\mathcal{F}$ Biol Chem 1951; 193: 265-75. 
21 Kapuscinski J, Skoczylas B. Simple and rapid fluorimetric method for DNA microassay. Anal Biochem 1977; 83: 252-7. 22 Chomczynski P, Sacchi N. Single-step method of phenol-chloriform extraction. Anal Biochem 1987; 162: 156-9.

23 Angelini G, de Praval C, Gorski J, Mach B. High-resolution analysis of the human HLA-DR polymorphism by analysis of the human HLA-DR polymorphism by hybridisation with sequence-specific oligon
probes. Proc Natl Acad Sci USA 1986; 83: 4489.

24 Snedecor GW, Cochran WG, Statistical methods. 8th ed. Ames, Iowa: Iowa State University Press, 1989: 53-63.

25 Feldman DS Jr, Hofmann R, Gagnon J, Simpson J. Statview II. Berkeley, CA: Abacus Concepts Inc, 1987.

26 Ponnappa BC, Hoek JB, Sarchet K, Rubin E. Dietary carbohydrate level determines the effect of long-term ethanol ingestion on rat pancreatic amylase content. $f \mathrm{Lab}$ Clin Med 1986; 107: 556-62.

27 Giorgi D, Bernard JP, Dagorn JC. Regulation of amylase messenger RNA concentration in rat pancreas by food content. $E M B O \mathcal{F}_{1}$ 1984; 3: 1521-4

28 Schick J, Verspohl R, Kern H, Scheele G. Two distinct adaptive responses in the synthesis of exocrine pancreatic enzymes to inverse changes in protein and carbohydrate in the diet. Am F Physiol 1984; 247: G6611-6.

29 Ponnappa BC, Hoek JB, Jubinski L, Rubin E. Ethanol withdrawal stimulates protein synthesis in rat pancreatic lobules. Biochim Biophys Acta 1990; 1036: 107-12.

30 Wilson IS, Colley PW, Sosula I Pirola RC Chapman BA Somer JB. Alcohol causes a fatty pancreas. A rat model of ethanol-induced pancreatic steatosis. Alcoholism Clin Exp ethanol-induced pancreatic steatosis. Alcoholism Clin Exp

31 Wilson JS, Korsten MA, Leo MA, Lieber CS. Combined effects of protein deficiency and chronic ethanol consumption on rat pancreas. Dig Dis Sci 1988; 33: 1250-9.

32 Quon MG, Kugelmas M, Wisner JR, Chandrasoma $P$ Valenzuela JE. Chronic ethanol consumption intensifies caerulein-induced acute pancreatitis in the rat. Int $\mathcal{F}$ Pancreatol 1992; 12: 31-9. 